\title{
Biochemical and genotoxicity assessment of a polluted urban river using the native fish Astyanax altiparanae Garutti \& Britski (Teleostei, Characidae)
}

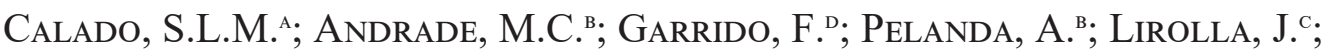 \\ SAlgado, L.D. ${ }^{\mathrm{D}}$; Cestari, M.M. ${ }^{\mathrm{C}}$ \& De Assis, H.C.S. ${ }^{\mathrm{B}}$ \\ ${ }^{a}$ Ecology and Conservation Program Post-Graduation, Federal University of Paraná \\ bepartment of Pharmacology, Federal University of Paraná \\ c Department of Genetics, Federal University of Paraná
}

Received August 08, 2019; Accept December 30, 2019

\begin{abstract}
Agriculture residues and domestic effluents are contaminants that reach aquatic ecosystems leading to toxic effects to environment and human health. These contaminants impacting mainly developing countries, due to precarious treatment of effluents and lack of legislation in the use of pesticides. Perequê River (South of Brazil) is impacted by pesticides (mainly glyphosate) and domestic effluents. The aims of this study were to analyze the concentration of glyphosate in water and sediments of Perequê River; and to evaluate the sublethal effects of the river contamination in Astyanax altiparanae using biomarkers. A sampling of water, sediment and fish were carried out in Perequê River (November/2016). The samples were collected in two sites, site 1 (S1) that is located on agriculture area and water catchment point; and site 2 (S2) located on the area with a domestic effluents influence. Water and sediment samples were used to glyphosate quantification. Fish were collected and tissues (brain, muscle, liver) were used to biochemical and genetic biomarkers. Glyphosate were quantified in S1, which is impacted by agriculture. Alterations in the liver biomarkers were not observed between the sites. However, the decrease in the $\mathrm{AChE}$ activity was observed in the $\mathrm{S} 2$, showing that the mixture of contaminants (urban and agriculture contaminants) can lead to anticholinesterasic effects. The sublethal effects observed can be a threat of environmental and human health.
\end{abstract}

Key-words: Biomarkers; Domestic effluents; Glyphosate; Perequê River.

\section{INTRODUCTION}

Anthropogenic activities have been caused the contamination of aquatic ecosystems and studies that evaluate this contamination and their toxic effects to the environment are increasingly required (Vieira et al., 2017). Agriculture, is one of this activities that results in several negative impacts to the environment such as soil degradation, deforestation and the soil and water contamination due to the use of the fertilizers and pesticides (Ren et al., 2018).

The pesticides are used since the 1940s in order to control the pests and increase of the food production improving the economic status of the countries. However, studies have been shown that its excessive use can cause environmental and human health problems (Plaza et al., 2019).

Therefore, due to the toxic effects of these substances, some pesticides as the DDT (organochlorine) and more currently the glyphosate (organophosphorus), were banned in several countries (Lan et al., 2019). Moreover, DDT is still used in Africa to control the malaria disease and the glyphosate is still used for agriculture in Latin America and USA (Yohannes et al., 2017).

Brazil is one of the most countries that produce and use pesticides to control pests in agriculture; and glyphosate, 
which is mainly used to rice, corn and soya planting has been showed several toxic effects such as cancer and risk to human health (Caldas, 2016), ovarian alteration and oxidative stress in mice (Ren et al., 2018); reproductive, epigenetic and behavior effects in fish (Smith et al., 2019). Despite the negative impacts caused by this chemical, there is still any Brazilian regulation of the maximum limits for these substances in drinking water or in aquatic organisms tissues.

In addition to the pesticide contamination in aquatic ecosystems, the indiscriminate discharge of domestic and industrial effluents in the water bodies, mainly seen in developing countries, also result in the environment contamination (Bueno-Krawczyk et al., 2015). These effluents are composed by a mixture of contaminants (e.g. pharmaceuticals and personal care products); and several studies have been reported the accumulation of these substances and toxic effects in aquatic organisms (ÁlvarezMuñoz et al., 2019).

Perequê River is located in Santa Catarina South of Brazil; which is used for water supply and is highly impacted by the rice cultivation (herbicides) and surroundings settlements (urban domestic effluents). These negative impacts in this water body can cause degradation of this ecosystem and problems to human health (Oliveira et al., 2019).

In order to monitor impacted environments, as Perequê River, ecotoxicological studies have been using biological models to evaluate the response of organisms to the contamination. Fish are a good biological model because they are constantly exposed to the environmental conditions and distributed in various trophic levels. Astyanax altiparanae (Garutti \& Britski, 2000) Teleostei, Characidae, is a freshwater fish with a wide distribution in the Neotropical region; and presents an ecological and economic importance (Bertolucci et al., 2008). In addition to the biological model, the use of biomarkers is an advantageous tool to evaluate the sublethal effects in different levels of organization (Guiloski et al., 2017). Studies that use this approach have contributed to evaluate toxic effects of xenobiotics and to monitor contaminated areas (Vieira et al., 2017).

Therefore, the aims of this study were to determine the concentration of glyphosate in water and sediment samples from the Perequê River; and evaluate the Astyanax altiparanae health using biochemical and genetic biomarkers.

\section{MATERIAL AND METHODS}

\section{Sampling}

Water, sediment and fish samples were collected in Perequê river $\left(48^{\circ} 37^{\prime} 58^{\prime \prime} \mathrm{W} 27^{\circ} 7^{\prime} 42^{\prime \prime} \mathrm{S}\right)$ in November 2016, the season that correspond to the rice development, after the herbicide spraying period (pre-harvest application). For the present study, two sampling sites were chosen to collect of the samples. The first one "Site 1" (270 08'44.1"S 48 $37^{\prime} 25.2^{\prime \prime} \mathrm{W}$ ) is located on agriculture area (rice planting) and water catchment point upstream of the accumulation dam; and the second one "Site 2" $\left(27^{\circ} 08^{\prime} 32.8^{\prime \prime} 48\right.$ 37'01.7'” $\left.\mathrm{W}\right)$ is located on the area with a domestic effluents influence, downstream of the accumulation dam.

The water samples were taken at a depth of $30 \mathrm{~cm}$ below the water surface and stored in dark bottles. In order to the preservation of the water samples, the $\mathrm{Na}_{2} \mathrm{~S}_{2} \mathrm{O}_{3}$ was added and the samples were maintained at $4^{\circ} \mathrm{C}$. Sediment samples were collected using a dredge and they were also maintained at $4^{\circ} \mathrm{C}$ (Cetesb, 2011). Both were used for chemical analysis of glyphosate, which were carried out $48 \mathrm{~h}$ later.

Immature fish Astyanax altiparanae were collected in both sites (Site 1: $n=17$; Site 2: $\mathrm{n}=14$ ), which were weighted (Site 1: $4.59 \pm 1.25$; Site 2: 6.69 \pm 2.30 ), lenghted (7.12 \pm 0.91 ; Site 2: $8.24 \pm 0.82)$, anesthetized with benzocaine $(0.0001 \%)$ and euthanized by medullar section. Brain, muscle and liver samples were collected to biochemical biomarkers. All samples were transported to the laboratory in liquid nitrogen and they were kept in $-80^{\circ} \mathrm{C}$ until the assays. Liver samples were also collected for comet assay, which were kept in microtubes with $1 \mathrm{~mL}$ of fetal bovine serum, stored on dark and at $4{ }^{\circ} \mathrm{C}$ until the procedure.

\section{Chemical analysis}

Water and sediment were extracted with alkaline solution, filtered with a $0.22 \mu \mathrm{m}$ nylon membrane filter and analyzed using high performance liquid chromatography with UV detection (HPLC-UV). The glyphosate analysis was carried out using a reverse-phase Kromasil ODS C18 column and a mobile phase (methanol, acetonitrile, $0.02 \mathrm{M}$ phosphate buffer; 15:5:80 - v/v/v) (Fang et al., 2014).

The flow-rate was $1.0 \mathrm{ml} / \mathrm{min}$ and the injection volume for each sample was $20 \mu \mathrm{L}$. The quantification limits (LOQ) of glyphosate were $60 \mu \mathrm{g} \mathrm{L}^{-1}$ for water samples and $10 \mu \mathrm{g} \mathrm{Kg}^{-1}$ for sediment samples.

\section{Biochemical Biomarkers}

Muscle and brain samples were homogenized using phosphate buffer at $\mathrm{pH} 7.5$ and centrifuged at $12000 \mathrm{x} \mathrm{g}$ for $20 \mathrm{~min}$ at $4{ }^{\circ} \mathrm{C}$. The supernatants were used to measure the acetylcholinesterase activity according to Ellman et al. (1961) modified for microplates by Silva de Assis (1998).

Liver samples were homogenized using phosphate buffer at $\mathrm{pH} 7.0$ and centrifuged at $15000 \mathrm{xg}$ for $30 \mathrm{~min}$ at $4{ }^{\circ} \mathrm{C}$. The supernatants were collected and used to measure the superoxide dismutase (SOD) (Gao et al., (1998), catalase (CAT) (Aebi, 1984), glutathione peroxidase (GPx) (Paglia and Valentine, 1967) and glutathione S-transferase (GST) (Keen et al., 1976) activities in order to evaluate the antioxidant system. The lipoperoxidation (LPO) (Jiang et al., 1992) was also analyzed in the liver samples in order to evaluate the lipid damage. 
The protein quantification was measured in muscle, brain and liver; and preceded all biochemical biomarkers. The total protein concentration was quantified using bovine serum albumin as a standard according the methodology proposed by Bradford (1976).

\section{Genetic Biomarkers}

Liver samples were also used to evaluate the comet assay. The tissues were homogenized with $1 \mathrm{~mL}$ fetal bovine serum according to methodology proposed by Singh et al. (1988), and modified by Ferraro et al. (2004).

\section{Statistical analysis}

The Levene's homogeneity test and Shapiro Wilk normality test were carried out for all data. In order to evaluate the difference of the biomarker responses in fish between the site samples (S1 and S2); the Student's t Test and MannWhitney test were used. The analysis were carried out using software R 3.2.2 (R Core Team 2015) and the significant level was $p<0.05$.

\section{RESULTS AND DISCUSSION}

Glyphosate concentrations in water samples were below of the quantification limit (>LOQ; $\mu \mathrm{g} \mathrm{L}^{-1}$ ) for both sampling sites. Glyphosate concentrations in sediment samples, as already reported in a previous study (see Oliveira et al., 2019), were found in site $1\left(11,7 \mu \mathrm{g} \mathrm{Kg}^{-1}\right)$ and the concentrations in site 2 were below of the quantification limit ( $>\mathrm{LOQ})$. Concentrations of glyphosate have been reported in aquatic environments worldwide such as Argentina (Berman et al., 2018), United States (Tush et al., 2018), Germany (Skeff et al., 2018) and China (Yang et al., 2015). In Brazil, there is not a legislation that determines the maximum limit of glyphosate in sediments and in tissues of aquatic organisms. Brazil has been among the top three pesticide markets in the world in the last 10 years (Lopes and Albuquerque, 2018); and for this reason it is extremely necessary to implement legislation that monitors and controls concentrations of pesticides in aquatic environments, mainly glyphosate that is one of the most used in agriculture. In addition, Perequê River is used to water supply of the Porto Belo city, Santa Catarina. Due to the pesticides effects also to human health as an increased cell proliferation (Sritana et al., 2018) and neurodevelopmental disorders (Van Bruggen et al., 2018); monitoring and the managements of these residues are required.

In the present study, glyphosate concentrations were found only in sediment samples. Glyphosate is readily absorbed to soil and studies have also detected this compound mainly in sediments and in higher concentrations than water samples (Tush et al., 2018; Van Bruggen et al., 2018). Therefore, benthonic species can be more affected by this pesticide. Several studies have reported toxic effects in aquatic organisms caused by glyphosate such as neurotoxicity and cardiovascular toxicity in fish (Roy et al., 2016); behavior changes in aquatic invertebrates (Hansen and Roslev, 2016); delay of gametogenesis in oysters (Mottier et al., 2015); imbalances in the hatching dynamics of egg in zooplankton (Gutierrez et al., 2017) and oxidative stress in polychaeta (Tarouco et al., 2017). In addition, the glyphosate concentrations were found only in the site 1 . This result was expected since the site 1 is a riziculture area that uses this herbicide and it can be more impacted. In addition, the dam in the water catchment point favors the glyphosate precipitation and adsorption in the sediment of point 1 . Glyphosate can reach the site 2, but in lower concentrations.

The biomarkers results showed differences between sites when we analyzed the AChE activity in brain and muscle samples. The AChE activity was lower in the site 2 (MannWhitney $=33.00, p=0.003$ (brain) $) ;(\mathrm{t}=3.14 p=0.004$ (muscle) $)$ (Figure 1). The other biochemical and genetic biomarkers evaluated were similar between sampling sites (Table 1).

Glyphosate is known to cause neurotoxicity, by inhibition of acetylcholinesterase activity in fish, invertebrate and mammal species (Van Bruggen et al., 2018). Acetylcholinesterase enzyme is responsible to breakdown acetylcholine, a neurotransmitter. The inhibition of this enzyme can hamper the transmission of the nerve impulse; causing neurotoxicity and in result to impact on the dynamics of ecosystems (Tan et al., 2018). Studies have showed the AChE inhibition in different organisms' exposure to glyphosate such as polychaeta (Tarouro et al., 2018); fish (Gholami-Seyedkolaei et al., 2013); and mussels (Sandrini et al., 2013). However, our results showed the lower AChE activity in fish from site 2, which is less impacted by agriculture and glyphosate concentrations was not quantified. The site 2 is an urban area characterized by the presence of anthropic activities such as settlements; industries; and sewage and wastewater disposal in the river. Therefore, a mixture of contaminants can be present in this water body and several other anticholinesterases agents, including glyphosate, may have caused the decrease of the AChE enzyme. In addition, A. altiparanae is a nektonic species, which is not dependent on the substrate during their life cycle, therefore this fish may be more affected by the contaminants that are available in the water column (Castro et al., 2004).

Other studies have been shown the higher decrease of AChE activity in urban areas when compared with the agriculture areas. They also suggested that the mixture of contaminants could cause more stress and impairment to the enzyme activity (Bueno-Krawczyk et al., 2015).

The other biomarkers results not showed differences between site 1 and site 2 . These data suggested that the fish were exposure to environmental stress in both sites since significant differences were not found. Both sites are impacted by anthropic activities resulting in similar responses in enzyme activity as well as DNA and lipid membrane damage. Vieira et al. (2017), also reported similar biomarkers responses when compared different impacted areas. Studies also showed that the main biomarkers responses were found seasonally and not spatially (Trujillo-Jiménez et al., 2011; Bueno-Krawczyk et al., 

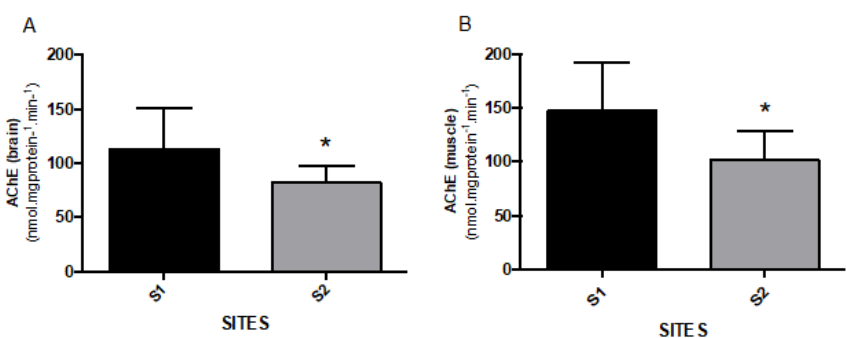

Figure 1: Acetylcholinesterase activity in brain (A) and muscle (B) samples. Site $1(n=17)$, Site $2(n=14)$.

*: Statistical difference between sites. The results were presented using Mean $\pm \mathrm{SD} ; p<0.05$.Student t Test and Mann-Whitney.

Table 1: Biomarkers in liver samples in Astyanax altiparanae collected in Perequê river

\begin{tabular}{lcc}
\hline BIOMARKERS & SITE 1 & SITE 2 \\
CAT & $171.03 \pm 22.96$ & $72.57 \pm 45.45$ \\
SOD & $121.94 \pm 29.15$ & $151.24 \pm 50.46$ \\
GPx & $61.80 \pm 21.84$ & $42.71 \pm 17.61$ \\
GST & $27.00 \pm 6.50$ & $21.50 \pm 6.48$ \\
LPO & $34.86 \pm 25.27$ & $32.48 \pm 12.79$ \\
Comet assay & $173.00 \pm 47.48$ & $178.66 \pm 44.34$
\end{tabular}

*: Statistical difference between sites. Site $1(n=17)$; Site 2 ( $n=14)$. The results were presented using Mean $\pm \mathrm{SD} ; \mathrm{P}<0.05$.

CAT: Catalase (activity $\mu \mathrm{mol} . \mathrm{min}^{-1} . \mathrm{mg} \cdot$ protein $^{-1}$ ); SOD:

Superoxide dismutase (SOD unity $\mathrm{mg}_{\text {protein }}{ }^{-1}$ ); GST: Glutathione S-transferase (activity nmol $\mathrm{min}^{-1} \mathrm{mg}_{\text {protein }}{ }^{-1}$ ); GPx: Glutathione peroxidase (activity nmol $\mathrm{min}^{-1} \mathrm{mg}_{\text {protein }}{ }^{-1}$ ); LPO: lipoperoxidation (hydroperoxides nmol mg protein ${ }^{-1}$ ).

2015). In the present study, the water, sediment and fish samples were collected in a period of lower rainfall index, and then it is possible that the differential dynamics of the environment and the different response of aquatic organisms may be mainly seasonal. This seasonal difference influencing the Perequê River was observed by Oliveira et al. (2019). This seasonality may be due to the pesticides application and the rainfall index.

In summary, as the Perequê River is used for water supply, the contamination by glyphosate and the urban contaminants; and the neurotoxic effects in fish is a threat to the conservation of this ecosystem and to human health.

\section{ACKNOWLEDGMENTS}

The authors thank CNPq (National Council for Scientific and Technological Development) and CAPES (National Council for the Improvement of Higher Education) - finance 001 ; for the financial support.

\section{REFERENCES}

AEBI, H. 1984. Catalase in vitro. Methods. Enzymol. 105: 121-126. https://dx.doi.org/10.1016/S0076-6879(84)05016-3

ÁLVAREZ-MUÑOZ, D., RAMBLA-ALEGRE, M., CARRASCO, N., LOPEZ DE ALDA, M., BARCELÓ, D. 2019. Fast analysis of relevant contaminats mixture in commercial shellfish. Talanta.
In press. https://dx.doi.org/10.1016/j.talanta.2019.04.085.

BERMAN, M.C., MARINO, D.J.G., QUIROGA, M.V., ZAGARESE, H. 2018. Ocurrence and levels of glyphosate and AMPA in shallow lakes from the Pampean and Patagonian regions of Argentina. Chemosphere, 200: 513-522. https:// dx.doi.org/10.1016/j.chemosphere.2018.02.103.

BERTOLUCCI， B.,VICENTINI, C.A.,VICENTINI, I.B.F., BOMBONATO, M.T.S. 2008. Light microscopy and ultrastructure of the liver of Astyanax altiparanae Garutti and Britski, 2000 (Teleostei, Characidae). Acta Sci. Biol. Sci. 30: 73-76. https://dx.doi.org/10.4025/actascibiolsci.v30i1.1456

BRADFORD, M. 1976. A rapid and sensitive method for the quantification of microgram quantities of protein utilizing the principle of protein-dye binding. Anal. Biochem. 72: 248254. https://dx.doi.org/10.1006/abio.1976.9999.

BUENO-KRAWCZYK, A.C.D., GUILOSKI, I.C., PIANCINI, L.D.S., AZEVEDO, J.C., RAMSDORF, W.A., IDE, A.H., GUIMARÃES, A.T.B., CESTARI, M.M., SILVA DE ASSIS, H.C. 2015. Multibiomarker in fish to evaluate a river used to water public supply. Chemosphere, 135: 257-264. http://dx.doi. org/10.1016/j.chemosphere.2015.04.064

CALDAS, E.D. 2016. Pesticide Poisoning in Brazil. Reference Module in Earth Systems and Environmental Sciences. https:// dx.doi.org/10.1016/B978-0-12-409548-9.10282-9

CASTRO, R.M.C., CASATTI, L., SANTOS, H.F., MELO, A.L.A., MARTINS, L.S.F., FERREIRA, K.M., GIBRAN, F.Z., BENINE, R.C., CARVALHO, M., RIBEIRO, A.C., ABREU, T.X., BOCKMANN, F.A., PELIÇÃO, G.Z., STOPIGLIA, R., LANGEANI, F. 2004. Estrutura e composição da ictiofauna de riachos da Bacia do Rio Grande na estado e São Paulo, Sudeste do Brasil. Biota Neotropica, 4 (nl). http://www.biotaneotropica. org.br/v4n1/pt/abstract?article+BN01704012004.

CETESB, 2011. Guia nacional de coleta e preservação de amostras: água, sedimento, comunidades aquáticas e efluentes líquidos/ Companhia Ambiental do Estado de São Paulo. Organizadores: Carlos Jesus Brandão [et al.]. - São Paulo: CETESB; Brasília: ANA.

ELLMAN, G.L., COUTNEY, K.O., ANDRES, V., FEATHERSTONE, R.M. 1961. A new and rapid colorimetric determination of acetylcholinesterase activity. Biochem. Pharmacol. 7: 88-95. https://dx.doi.org/10.1016/00062952(61)90145-9.

FANG, F., WEI, R., LIU, X. 2014. Novel pre-column derivatisation reagent for glyphosate by high-performance liquid. Int. J. Environ. Anal. Chem. 94: 7. https://dx.doi.org/10.1080/03067 319.2013.864648.

FERRARO, M.V.M., FENOCCHIO, A.S., MANTOVANI, M.S., DE OLIVEIRA RIBEIRO, C.A., CESTARI, M.M. 2004. Mutagenic effects of tributyltin and inorganic lead ( $\mathrm{Pb}$ II) on the fish $H$. malabaricus as evaluated using the comet assay and the piscine micronucleus and chromosome aberration tests. Genet. Mol. Biol. 27: 103-107. http://dx.doi.org/10.1590/S141547572004000100017 .

GAO, R., YUAN, Z., ZHAO, Z., GAO, X. 1998. Mechanism of pyrogallol autoxidation and determination of superoxide dismutase enzyme activity. Bioelectrochem. Bioenerg. 45: 4145. https://dx.doi.org/10.1016/S0302-4598(98)00072-5.

GHOLAMI-SEYEDKOLAEI, S.J., MIRVAGHEFI, A., FARAHMAND, H., KOSARI, A.A. 2013. Effect of a glyphosate-based herbicide in Cyprinus carpio: Assessment of acetylcholinesterase activity, hematological responses and serum biochemical parameters. Ecotoxicol. Environ. Saf. 98: 135-141. https://dx.doi.org/10.1016/j.ecoenv.2013.09.011.

GUILOSKI, I.C., RIBAS, J.L., PIANCINI, L.D.S., DAGOSTIM, 
A.C., CALADO, S.L.M.; FÁVARO, L.F., BOSCHEN, S.L., CESTARI, M.M., CUNHA, C., SILVA DE ASSIS, H.C. 2017. Effects of environmentally relevant concentrations of the antiinflammatory drug diclofenac in freshwater fish Rhamdia quelen. Ecotoxicol. Environ. Saf. 139: 291-300. https://dx.doi. org/10.1016/j.ecoenv.2017.01.053.

GARUTTI, V. \& H.A. BRITSKI. 2000. Descrição de uma espécie nova de Astyanax (Teleostei: Characidae) da bacia do alto rio Paraná e considerações sobre as demais espécies do gênero na bacia. Comun. Mus. Cienc. Tecnol. Pucrs. Ser. Zool., Porto Alegre, 13: 65-88.

GUTIERREZ, M.F., BATTAUZ, Y., CAISSO, B. 2017. Disruption of the hatching dynamics of zooplankton egg banks due to glyphosate application. Chemosphere, 17: 644-653. http://dx.doi. org/10.1016/j.chemosphere.2016.12.110.

HANSEN, L.R., ROSLEV, P. 2016. Behavioral responses of juvenile Daphnia magna after exposure to glyphosate-copper complexes. Aquat. Toxicol. 179: 36-43. http://dx.doi.org/10.1016/j. aquatox.2016.08.010.

JIANG, Z-Y., HUNT, J.V., WOLFF, S.P. 1992. Ferrous ion oxidation in the presence of xylenol orange for detection of lipid hydroperoxide in low density lipoprotein. Anal. Biochem. 202: 384-389. https://dx.doi.org/10.1016/0003-2697(92)90122-n.

KEEN, J.H., HABIG, W.H., JAKOBY, W.B. 1976. Mechanism for several activities of the glutathione S-transferases. J. Biol. Chem. 251: 6183-6188.

LAN, J., JIA, J., LIU, A., YU, Z., ZHAO, Z. 2019. Pollution levels of banned and non-banned pesticides in surface sediments from the East China Sea. Mar. Pollut. Bull. 139: 332-338. https://dx.doi. org/10.1016/j.marpolbul.2019.01.006.

LOPES, C.V.A., ALBUQUERQUE, G.S.C. 2018. Agrochemicals and theis impacts on human and environmental health: a systematic review. Saúde debate. 47: 518-534. https://dx.doi. org/10.1590/0103-1104201811714.

MOTTIER, A., SÉGUIN, A., DEVOS, A., PABIC, C.L., VOISEUX, C., LEBEL, J.M., SERPENTINI, A., FIEVET, B., COSTIL, K. 2015. Effects of subchronic expousure to glyphosate in juvenile oysters (Crassostrea gigas): From molecular to individual levels. Mar. Pollut. Bull. 95: 665-677. http://dx.doi.org/10.1016/j. marpolbul.2014.10.026.

OLIVEIRA, F.G.; LIROLA, J.R.; SALGADO, L.D.; MARCHI, G.H.; MELA, M.; PADIAL, A.A.; GUIMARÃES, A.T.B.; CESTARI, M.M.; DE ASSIS, H.C.S. 2019. Toxicological effects of anthropogenic activities in Geophagus brasiliensis from a coastal river of southern Brazil: A biomarker approach. Sci. Total Environ. 667: 371-383. https://dx.doi.org/10.1016/j. scitotenv.2019.02.168.

PAGLIA, D., VALENTINE, W. 1967. Studies on the quantitative and qualitative charactization of erythrocyte glutathione peroxidase. J. Lab. Clin. Med. 70: 158-169.

PLAZA, P.I., MARTÍNEZ-LOPES, E., LAMBERTUCCI, S.A. 2019. The perfect threat: Pesticides and vultures. Sci. Total Environ. In press. https://dx.doi.org/10.1016/j.scitotenv.2019.06.160.

REN, X., LI. R., HUANG, K., WU, S., LI, Y., LI. C. 2018. Effects of glyphosate on the ovarian function of pregnant mice, the secretion of hormones and the sex ratio of their fetuses. Environ. Poll. 243: 833-841. doi: 10.1016/j.envpol.2018.09.049.

ROY, N.M., CARNEIRO, B., OCHS, J. 2016. Glyphosate induces neurotoxicity in zebrafish. Environ. Toxicol. Pharmacol. 42: 4554. http://dx.doi.org/10.1016/j.etap.2016.01.003.

SANDRINI, J.Z., ROLA, R.C., LOPES, F.M., BUFFON, H.F., FREITAS, M.M., MARTINS, C.M.G., ROSA, C.E. 2013. Effects of glyphosate on cholinesterase activity of the mussel Perna perna and the fish Danio rerio and Jenynsia multidentata:
In vitro studies. Aquat. Toxicol. 130-131: 171-173. http://dx.doi. org/10.1016/j.aquatox.2013.01.006.

SILVA DE ASSIS, H.C. 1998. Der Einsatz von Biomarkern zur summarischen Erfassung vom Gewässerverschmutzungen. $\mathrm{PhD}$ thesis, Berlin Technical University, Berlin, Germany.

SINGH, N.P., MCCOY, M.T., TICE, R.R., SCHNEIDER, E.L. 1998. A simple technique for quantification of low levels of DNA damage in individual cells. Exp. Cell. Res. 175: 184-191. https://dx.doi.org/10.1016/0014-4827(88)90265-0.

SKEFF, W., RECKNAGEL, C., DUWEL, Y., SCHULZ-BULL, D.E. 2018. Absorption behaviors of glyphosate, glufosinate, aminomethylphosphonic acid, and 2-aminoethylphosphonic acid on three typical Baltic Sea sediments. Mar. Chem. 198: 1-9. https://dx.doi.org/10.1016/j.marchem.2017.11.008.

SMITH, C.M., VERA, M.K.M., BHANDARI, R.K. 2019. Developmental and epigenetic effects of Roundup and glyphosate exposure on Japanese medaka (Oryzias latipes). Aquat. Toxicol. 210: 215-226. https://dx.doi.org/10.1016/j.aquatox.2019.03.005.

SRITANA, N., SURIYO, T., KANITWITHAYANUN, J., SONGVASIN, B.H., THIANTANAWAT, A., SATAYAVIVAD, J. 2018. Food Chem. Toxicol. 118: 595-607. https://dx.doi. org/10.1016/j.fct.2018.06.014.

TAN, E.C.K., JOHNELL, K., GARCIA-PTACEK, S., HAAKSMA, M.L., FASTBOM, J., BELL, S.J., ERIKSDOTTER, M. 2018. Acetylcholinesterase inhibitors and risk of stroke and death in people with dementia. Alzheimer's \& Dementia, 1-8. https:// dx.doi.org/10.1016/j.jalz.2018.02.011.

TAROUCO, F.M., GADOI, F.G.A., VELASQUES, R.R., GUERREIRO, A.S., GEIHS, M.A., ROSA, C.E. 2017. Effects of the herbicide Roundup on the polychaeta Laeonereis acuta: Cholinesterases and oxidative stress. Ecotoxicol. Environ. Saf. 135: 259-266. http://dx.doi.org/10.1016/j.ecoenv.2016.10.014.

TRIJILLO-JIMÉNEZ, P., DIAZ, J.E.S., CAMARGO, J., LÓPEZLÓPEZ, E. 2011. Assessing environmental conditions of the Río Champotón (México) using diverse indices and biomarkers in the fish Astyanax aeneus (Günther, 1860). Ecol. Indic. 11: 16361646. https://dx.doi.org/10.1016/j.ecolind.2011.04.007.

TUSH, D., MAKSIMOWICZ, M.M., MEYER, M.T. 2018 Dissipation of polyoxyethylene tallow amine (POEA) and glyphosate in an agricultural field and their co-occurrence on streambed sediments. Sci. Total Environ. 636: 212-219. https:// dx.doi.org/10.1016/j.scitotenv.2018.04.246

VAN BRUGGEN, A.H.C., HE, M.M., SHIN, K., MAI, V., JEONG, K.C., FINCKH, M.R., MORRIS, J.G.JR. 2018. Sci. Total Environ. 616-617: 255-268. https://dx.doi.org/10.1016/j. scitotenv.2017.10.309.

VIEIRA, C.E.D., COSTA, P.G., CABRERA, L.C., PRIMEL, E.G., FILLMANN, G., BIANCHINI, A., BUENO DOS REIS MARTINEZ, C. 2017. A comparative approach using biomarkers in feral and caged Neotropical fish: Implications for biomonitoring freshwater ecosystems in agricultural areas. Sci. Total Environ. 586: 598-609. https://dx.doi.org/10.1016/j. scitotenv.2017.02.026.

YANG, X., WANG, F., BENTO, C.P.M., MENG, L., DAM, R.V., MOL, H., LIU, G., RITSEMA, C.J., GEISSEN, V. 2015. Decay characteristics and erosion-related transport of glyphosate in Chinese loess soil under field conditions. Sci. Total Environ. 530531: 87-95. http://dx.doi.org/10.1016/j.scitotenv.2015.05.082.

YOHANNES, Y.B., IKENAKA, Y., NAKAYAMA, S.M.M., MIZUKAWA, H., ISHIZUKA, M. 2016. DDTs and other organochlorine pesticides in tissues of four bird species from the Rift Valley region, Ethiopia. Sci. Total Environ. 574: 1389-1395. https://dx.doi.org/10.1016/j.scitotenv.2016.08.056 